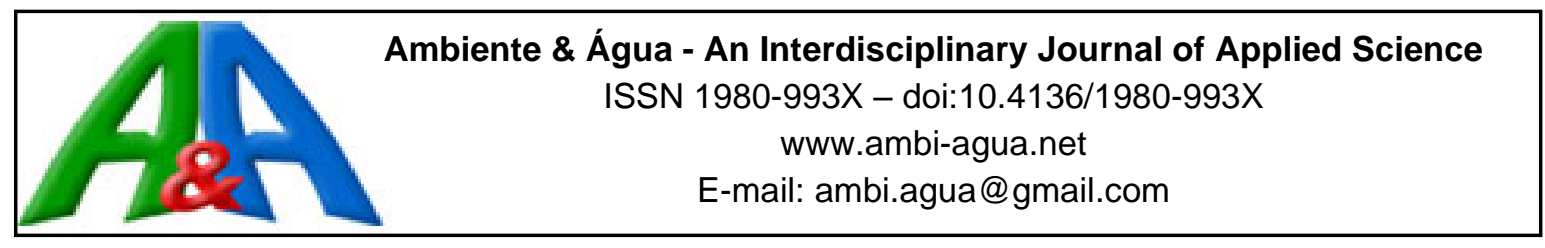

\title{
Polymer coating in soybean seed treatment and their relation to leaching of chemicals
}

\author{
ARTICLES doi:10.4136/ambi-agua.2602
}

Received: 18 Jun. 2020; Accepted: 28 Sep. 2020

\begin{abstract}
Eduardo José Ludwig $^{1 *(D)}$; Ubirajara Russi Nunes1 ${ }^{1}$; Osmar Damian Prestes ${ }^{2}{ }^{(D}$; Lovane Klein Fagundes ${ }^{1}$; ; Tiéle Stuker Fernandes ${ }^{1}{ }^{(D}$; Nathália Saibt ${ }^{2}[\mathbb{i}$

${ }^{1}$ Departamento de Fitotecnia. Universidade Federal de Santa Maria (UFSM), Avenida Roraima, nº 1000, CEP: 97105-970, Santa Maria, RS, Brazil. E-mail: russinunes@yahoo.com.br, lovklein@yahoo.com.br, tielefernandes@hotmail.com

${ }^{2}$ Departamento de Química. Universidade Federal de Santa Maria (UFSM), Avenida Roraima, no 1000 , CEP: 97105-970, Santa Maria, RS, Brazil. E-mail: osmar.prestes@ufsm.br, nattiesaibt@hotmail.com *Corresponding author. E-mail: eduludwig@yahoo.com.br
\end{abstract}

\begin{abstract}
This study evaluated the physiological quality and quantified the efficiency of polymer in reducing the loss of phytosanitary products by leaching from soybean seeds of different diameters and in different treatments. Two lots of seed and two types of treatments were tested: polymers associated with seed treatment, and polymer application in layers after the seed treatment. For that, the following treatments were analyzed: Control= no seed treatment; Treat + pol $=$ seed treatment + polymers in the mix; Treat/pol $=$ seed treatment + polymers applied in layers; Treat $=$ seed treatment. To evaluate seed treatment retention by the polymers, extraction equipment was employed and leaching of the active ingredient thiamethoxam was quantified. Evaluation of physical quality was conducted with tests of germination rate, first count, emergence rate, accelerated aging, seedling length, seedling dry mass and moisture content. Polymer application associated with seed treatment was efficient in reducing losses by leaching, reducing product loss by $20 \%$. No significant differences in retention and physiological quality were found when different methods for polymer application were compared. Bigger seeds presented greater vigor, but the germination rate was unaffected.
\end{abstract}

Keywords: film coating, Glycine $\max$ (L.) Merrill, layer treatment.

\section{Polímeros no tratamento de sementes de soja e sua relação com a lixiviação de produtos químicos}

\section{RESUMO}

O objetivo deste trabalho foi avaliar a qualidade fisiológica e quantificar a eficácia do polímero na retenção de perdas por lixiviação do tratamento fitossanitário em sementes de soja com diferentes diâmetros e tratadas sob diferentes formas. Foram utilizados dois lotes de sementes com diferentes diâmetros e foram realizadas duas formas de aplicação do tratamento: polímero associados ao tratamento fitossanitário na mesma calda e aplicação do polímero em camada após o tratamento, sendo os tratamentos formados da seguinte maneira: Control= sem tratamento, Treat + pol $=$ Tratamento fitossanitário + polímero aplicados na mesma calda, Treat/pol $=$ Tratamento fitossanitário + polímero aplicados em camadas, Treat $=$ Tratamento 
fitossanitário. Para avaliação da retenção do tratamento pelo polímero foi utilizado um extrator e realizada a quantificação do ingrediente ativo tiametoxam lixiviado. Para avaliação da qualidade fisiológica foram realizados os testes de germinação, primeira contagem, emergência, envelhecimento acelerado, comprimento de plântulas, massa seca de plântulas e grau de umidade. A aplicação de polímero associado ao tratamento fitossanitário de sementes foi eficiente na diminuição das perdas por lixiviação, reduzindo em $20 \%$ a perda de produtos. Não houve diferença na capacidade de retenção e na qualidade fisiológica entre as diferentes formas de aplicação do polímero. Sementes de maior tamanho apresentam maior vigor, porém a germinação não é afetada.

Palavras-chave: Glycine max (L.) Merrill, tratamento em camadas, peliculização.

\section{INTRODUCTION}

The establishment of soybean seedling in the field is a critical step for achieving success in the following growth phases of the crop. However, there are several factors that can hinder the development of the seedling stand. Pests and pathogen attacks can be considered major causes of reduced germination, and consequently, lower physiological quality of seeds (Zhang et al., 2016; Hesler et al., 2018).

Seed treatment aims to protect seeds against these diverse factors. By providing adequate conditions for the establishment of seedlings and benefiting the following growth phases, the procedure maintains the physiological and sanitary quality of seeds (Arfaoui et al., 2018). The methods generally consist of applying chemicals that protect seeds against adverse effects. Thus, attacks during the seedling's establishment are controlled, and crop emergence and development are stimulated (Balardin et al., 2011).

Among the current challenges in seed treatment are the development of lower doses, more effective and less pollutant active ingredients, and improving the adherence of chemicals (Lima et al., 2006). Detected problems in seed treatment include the formation of toxic dust and loss of chemical due to leaching. In regard to the latter problem, the use of chemicals in agriculture possess risks of groundwater contamination (Castro et al., 2008).

Polymers can be applied in association with fungicides and insecticides for seed treatment. Seed film coating is a method in which seeds are covered with polymers that increase the adherence of chemicals, thereby reducing risks of environmental contamination, formation of dust, attacks by fungi and moisture absorption during storage (Accinelli et al., 2016; Avelar et al., 2012; Vijaya Mahantesh et al., 2017). Ioannou et al. (2020) argue that polymers have been used as seed coatings, allowing the encapsulation and controlled release of pesticides used against pathogens, pests and insects that may interfere with seed germination. Using polymers for seed coating was found to benefit corn (Avelar et al., 2012) and rice (Fagundes et al., 2017).

The recent increases in the use of industrial seed treatment, which involves innovative equipment, and techniques such as the formulation of mixes containing fungicides, insecticides and nematicides can maximize the efficiency of the products, protect operators and reduce environmental contamination (Brzezinski et al., 2015). There is also equipment that allows the application of separate mixes during the seed treatment, thereby creating layers of chemicals.

Few studies investigated the relation between seed size and treatment, since the latter is commonly done considering the mass of seeds rather than their superficial area. Considering that a certain mass constituted by smaller seeds will present a larger superficial area than an equal mass of bigger seeds, the seed size can influence the efficiency of seed coating. Furthermore, seed size can possibly affect the physiological quality. A previous study reports the influence of seed size on the physiological quality, in which larger seeds presented higher physiological quality (Pádua et al., 2010). Contrarily, other authors suggest that these two 
characters are unrelated (Camozzato et al., 2009). According to Carvalho and Nakagawa (2012), seed size has no influence on germination, but affects seedling vigor. These authors reported that larger seeds originated more vigorous seedlings and might result in superior stands in fields with variable conditions. An advantage of smaller seeds is the larger ratio of surface area to volume which facilitates the absorption of water necessary for germination in soil (Kopper et al., 2010).

Studies on the relation between seed treatment and seed size are incipient. Therefore, the present work evaluated physiological quality and quantified the efficiency of a polymer in retaining chemicals on soybean seeds of different diameters and treated by different methods.

\section{MATERIAL AND METHODS}

The experiment was conducted in the Seeds Didactics and Research Laboratory and Pesticide Waste Analysis Laboratory, both of the Universidade Federal de Santa Maria.

Two seed lots from cultivar Nidera NA5909 were tested. The lots were collected in the field and their differentiation was based on sieve diameter. Therefore, seed retained in 5.5 to $6.0 \mathrm{~mm}$ sieves composed the $5.5 \mathrm{~mm}$ lot, whereas seeds retained in the $6.5-7.0 \mathrm{~mm}$ sieves composed the $6.0 \mathrm{~mm}$ lot.

Prior to seed treatment, the physiological quality of the seed lots were evaluated using tests of germination, first count, 1,000-seed weight and moisture content, according to the methodology described in Brazil (2009).

The chemical applied in the seed treatment was Avicta Completo® $\left(85 \mathrm{~g} \mathrm{~L}^{-1}\right.$ Abamectin + $115 \mathrm{~g} \mathrm{~L}^{-1}$ Thiamethoxam $+4 \mathrm{~g} \mathrm{~L}^{-1}$ Fludioxonil) at a dose of $6 \mathrm{~mL} \mathrm{~kg}^{-1}$ of seeds. The polymer Likoseed Vermelho® was applied in a dose of $1 \mathrm{~mL} \mathrm{~kg}^{-1}$ of seeds. The products were applied using two methods: polymers in association with seed treatment in the same mix; and polymer applied in a different mix after the seed treatment, which resulted in a layer treatment. Therefore, the following treatments were established: Control= no seed treatment; Treat+pol= seed treatment + polymer in the same mix; Treat/pol $=$ seed treatment + polymer applied in layers; Treat $=$ seed treatment.

In the treatments Treat+pol, the chemical and polymer were added in a unique mix used for seed treatment. Similarly, the treatment Treat involved a unique mix with the chemical. Otherwise, treatment Treat/pol involved separate applications of the seed treatment mix followed by the polymer mix. The later mix was applied after a homogenization step and included water in a concentration of $5 \mathrm{~mL} \mathrm{~kg}^{-1}$ of seed to form the required minimum volume of $6 \mathrm{~mL} \mathrm{~kg}^{-1}$. This polymer and water mix did not exceed the maximum volume of $14 \mathrm{~mL} \mathrm{~kg}^{-1}$, which results in no negative effect on physiological quality of seeds (Segalin et al., 2013).

The seed treatments were conducted in the center for seed treatment of COTRIBÁ, RS, BRAZIL. A model Momesso Arktos Africa batch treating machine was used for applying the mixes of treatments Treat+pol and Treat; and the two distinct mixes for treatment Treat/pol.

The extraction equipment used for measuring the leaching of chemicals from treated seeds was made of PVC pipes $(15 \mathrm{~cm}$ height and diameter of $4.6 \mathrm{~cm}$ ) placed side by side on a wooden support (Figure 1). A paper filter tied to the tubes was employed for covering the inferior part, as described by Fagundes et al. (2017). Furthermore, the equipment was filled with $7 \mathrm{~cm}$ of washed, sieved and sterilized sand. Five seeds from each of the four tested treatments were placed in the tubes and covered by $3 \mathrm{~cm}$ of the sand. Thus, the equipment simulated a $10 \mathrm{~cm}$ layer of soil in which seeds were sown at a $3 \mathrm{~cm}$ depth.

Simulated rainfall of $50 \mathrm{~mm}$ was applied for $20 \mathrm{~min}$ on the sand substrate that contained the seeds and was already saturated at $100 \%$ of water-holding capacity. The leached solution was collected in glass flasks placed under the tubes and taken for analyses at the LARP. Presence of the active ingredient Thiamethoxam in the samples was detected employing Ultra- 
High Performance Liquid Chromatography-tandem Mass Spectrometry (UHPLC-MS/MS) analyses, as described by Kemmerich et al. (2014).

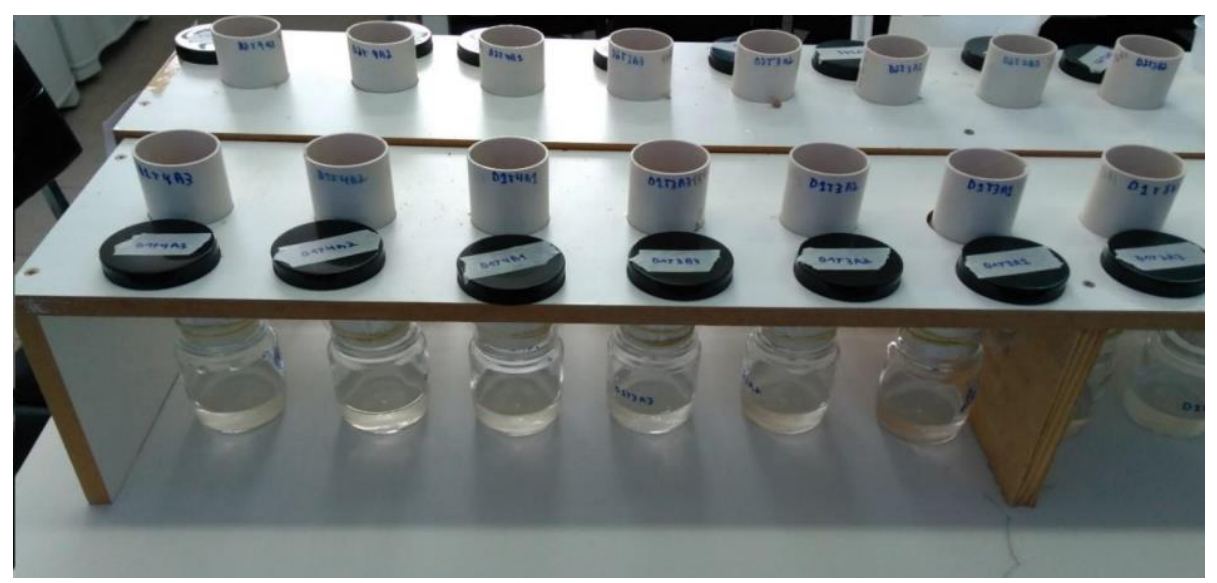

Figure 1. Extractor used for the simulated precipitation experiment and collection of leachate material.

Physiological quality of seeds with different diameters and treated with polymers in different methods were evaluated by the following tests:

Germination tests: performed according to the Rules for Seed Analyses (Brasil, 2009). Four repetitions of 50 seeds were sown on germitest paper rolls moistened with a water volume of 2.5 times the rolls' dry weight. The water used to hydrate the rolls had a $\mathrm{pH}$ of 5.8. These rolls were placed in a germinator at $25^{\circ} \mathrm{C}$ for eight days with constant light. Measurements were conducted afterwards and expressed as percentages of normal seedlings.

First count of the germination test: performed jointly with the germination test by computing the mean value of normal seedlings after five days of the sowing. Results were expressed as the percentage of normal seedlings.

Field emergence: four repetitions of 50 seeds from each treatment were sown at depth of $0.02 \mathrm{~m}$ in lines $1.0 \mathrm{~m}$ wide and spaced $0.20 \mathrm{~m}$ apart from each other. The percentage of seedlings emergence was evaluated 14 days after the sowing.

Accelerated aging: performed using the gerbox method with $40 \mathrm{~mL}$ of distilled water at $41^{\circ} \mathrm{C}$ for 48 hours. After that period, four repetitions of 50 seeds from each treatment were evaluated with the germination test. The counting was performed five days after the sowing.

Seedling length: four repetitions of 20 seeds from each treatment were sown in three lines on the superior part of germitest paper rolls. The rolls were placed in plastic bags and placed in a B.O.D incubator at $25^{\circ} \mathrm{C}$. Radicle and hypocotyl lengths of 10 randomly selected seedlings were measured using a millimeter ruler and the results were expressed in $\mathrm{cm}$ per seedling.

Radicle dry mass: after evaluating the seedling lengths, cotyledons were removed and the seedlings were placed in paper bags. After a 48 hours incubation period inside a germinator at $65 \pm 2^{\circ} \mathrm{C}$, the bags were weighted using a precision scale $(0.001 \mathrm{~g})$. The obtained masses were divided by the number of normal seedlings and the results were expressed in milligrams per seedling (mg seedling $\left.{ }^{-1}\right)$

Moisture content: determined using the laboratory stove method at $105^{\circ} \mathrm{C} \pm 3^{\circ} \mathrm{C}$ for 24 hours. Two repetitions containing $5 \pm 0.5 \mathrm{~g}$ of seed for each experimental unit were tested (Brasil, 2009)

The experiment had a completely randomized design in $2 \times 4$ factorial arrangement (seed lots $x$ seed treatment). For data analyses, variance analysis and comparison of means using the Scott-Knott test at the 5\% significance level in the statistical software Sisvar were calculated. Variables represented as percentages were transformed using $\arcsin \sqrt{\mathrm{x} / 100}$. 


\section{RESULTS AND DISCUSSION}

Initial evaluation of the two seed lots indicated that they did not present significant differences of physiological quality (Table 1). Nonetheless, the weight of 1,000 seeds differed between them due to the difference in size of the seeds.

Table 1. Average weight of 1,000 seeds (AW), first count (FC) and germination rate (G) from two soybean seed lots of the cultivar Nidera NA 5909.

\begin{tabular}{cccc}
\hline Diameter & AW $(\mathrm{g})$ & $\mathrm{FC}(\%)$ & $\mathrm{G}(\%)$ \\
\hline 5.5 & $146.3 \mathrm{a} *$ & $78 \mathrm{a}$ & $88 \mathrm{a}$ \\
6.5 & $181.2 \mathrm{~b}$ & $76 \mathrm{a}$ & $84 \mathrm{a}$ \\
\hline $\mathrm{CV}(\%)$ & 0.86 & 3.35 & 6.65 \\
\hline
\end{tabular}

* Different letters in the columns indicate means with statistically significant difference by the Scott-Knott test at the 5\% significance level.

For estimating the amount of active ingredient on the seeds (Table 2), a calculation was done using the concentration of the active ingredient in the commercial product and in the mix applied on the seeds, and the weight of 1,000 seeds from the two loots.

Table 2. Measured mass (mg) before and after leaching and percentage of the leached active ingredient (A.I.) Thiamethoxam $(\%)$ from five soybean seeds of the cultivar Nidera NA 5909. Seeds presented two distinct diameters, and underwent phytosanitary and polymers treatments and simulated rainfall.

\begin{tabular}{cccc}
\hline \multirow{2}{*}{ Diameter } & Initial A.I. & \multicolumn{2}{c}{ Leached A.I. } \\
\cline { 2 - 4 } & $\mathrm{Mg}$ & $\mathrm{Mg}$ & $\%$ \\
\hline 5,5 & 0,512 & $0,274 \mathrm{a}^{*}$ & $53,64 \mathrm{a}$ \\
6,5 & 0,634 & $0,342 \mathrm{~b}$ & $53,97 \mathrm{a}$ \\
\hline $\mathrm{CV}(\%)$ & - & 17,43 & 16,74 \\
\hline
\end{tabular}

* Different letters in the columns indicate means with statistically significant differences in the Scott-Knott test at the 5\% significance level. ${ }^{\text {ns: }}$ non-significant in the $\mathrm{F}$ test at $5 \%$ probability.

In the evaluation of chemicals leached, the results indicated a significant difference in the amount of the active ingredient thiamethoxam leached from seeds with different diameters, with more leaching detected from the larger seeds. This is due to the different weight of 1,000 seeds from the two lots. Larger seeds will have a smaller number of seeds per kilogram and consequently, smaller specific surface area. This difference was not observed when the comparison involved the percentage of leachate and the total active ingredient present. This is due to the fact that the guidelines for soybean seed treatment consider the mass rather than the number of seeds.

To become efficient, a sufficient quantity of chemicals needs to be applied and they must present a uniform distribution on the seeds. Thus, there is a need for correct technical information, and companies in the seed treatment market must investigate the factor seed size and give specific recommendations that aim for more efficient seed treatments. 
A significant difference in the factor seed treatment (Table 3) was found when seeds treated with polymer were compared to those only treated with the chemical. No significant difference was found when the different methods for applying the polymer were compared.

Table 3. Measured mass (mg) before and after leaching and percentage of leached active ingredient (A.I.) Thiamethoxam (\%) from five soybean seeds of the cultivar Nidera NA 5909, which underwent different phytosanitary and polymers treatments.

\begin{tabular}{cccc}
\hline \multirow{2}{*}{ Treatment } & \multicolumn{2}{c}{ Initial A.I. } & \multicolumn{2}{c}{ Leached A.I. } \\
\cline { 2 - 4 } & $\mathrm{Mg}$ & $\mathrm{mg}$ & $\%$ \\
\hline Control & 0 & $0 \mathrm{nd}^{*}$ & $0 \mathrm{nd}$ \\
Treat+pol & 0.574 & $0.268 \mathrm{a}^{1}$ & $46.67 \mathrm{a}$ \\
Treat/pol & 0.574 & $0.271 \mathrm{a}$ & $47.19 \mathrm{a}$ \\
Treat & 0.574 & $0.386 \mathrm{~b}$ & $67.56 \mathrm{~b}$ \\
\hline CV $(\%)$ & & 17.43 & 16.74 \\
\hline
\end{tabular}

*not detected by the used method. ${ }^{1}$ Different letters in the columns indicate means with statistically significant differences in the Scott-Knott test at the 5\% significance level.

The present results show that the use of polymers in both seed and layer treatment mixes was efficient in reducing the loss of the active ingredient Thiamethoxam by leaching in the simulated rainfall test. This result corroborates studies on corn by Avelar et al. (2012) and rice by Fagundes et al. (2017), who achieved reduced losses by leaching from the sand column and reported that the application of polymer promoted more adherence of chemicals on the seeds. This result indicates that the tested product is compatible and reflected on higher adhesion of the chemical on the seeds. Therefore, it ensured better seed protection and can reduce environmental impacts, such as soil contamination and pesticide leaching to groundwater.

To be considered adequate, a polymer must present determined characteristics. The coating must be stable in seed handling conditions encountered during the manufacturing, storage, distribution and sowing, be compatible with material to be incorporated with it, and must not be persistent in the soil after sowing (Accinelli et al., 2016). The retention of products used for seed treatment also depends on the adhesion of the applied product, compatibility among different formulations and the characteristics of the seed coating (Avelar et al., 2012).

The concentration of leached products may also vary according to the soil. According to Castro et al. (2008), the active ingredient thiamethoxam is highly leached from Red Latosol and less leached from Yellow-Red Latosol. This is due to soil characteristics, such as structure, sorption and compound degradation by this soil.

Leaching is related to the land cover, and consequently, uncovered soils may present faster leach than, for instance, no-till ones. The risk of groundwater contamination at levels which are toxic to humans depends on the groundwater depth and product toxicity (Castro et al., 2008).

The polymer application methods were not statistically different. Therefore, seed handling equipment should be better designed and more adequate, so that the polymer can more efficiently retain the chemical products and losses by leaching can be further reduced.

Looking at the total percentage of leachate, the use of polymer in the seed treatment prevented a loss of about $20 \%$ of the active ingredient when compared to the seed treatment without polymer. With more chemicals being retained on the seed, the treatment protects them more effectively and they may show better initial development under adverse conditions. In 
addition to greater seed protection, there is an environmental benefit as less product is leached into the soil.

In regard to physiological quality, the isolated effects of diameter and seed treatment were statistically significant for some variables (Table 4). Concerning the seed diameter effect, no statistically significant difference was found by analyzing the results of parameters vigor (FC), germination $(\mathrm{G})$, field emergence (FE), radicle length (RL) and hypocotyl length (HL).

Table 4. Means of the first count (FC), germination rate $(\mathrm{G})$, emergence in the field (FE), accelerated aging (AA), radicle length (RL), hypocotyl length (HL), dry mass (DM) and moisture content (MC) test results from soybean seeds presenting different diameters.

\begin{tabular}{ccccccccc}
\hline Diameter & FC $(\%)$ & G $(\%)$ & FE $(\%)$ & AA $(\%)$ & RL $(\mathrm{cm})$ & HL $(\mathrm{cm})$ & DM $(\mathrm{mg})$ & MC $(\%)$ \\
\hline 5.5 & $81^{\text {ns }}$ & $89^{\text {ns }}$ & $86^{\text {ns }}$ & $71 \mathrm{~b}^{*}$ & $13.66^{\text {ns }}$ & $6.78^{\text {ns }}$ & $28.65 \mathrm{~b}$ & $11.31^{\text {ns }}$ \\
6.5 & 79 & 89 & 86 & $79 \mathrm{a}$ & 13.84 & 6.31 & $31.71 \mathrm{a}$ & 11.44 \\
\hline $\mathrm{CV}(\%)$ & 6.43 & 6.79 & 5.03 & 5.42 & 7.6 & 9.9 & 5.97 & 0.5 \\
\hline
\end{tabular}

* Different letters in the columns indicate means with statistically significant differences in the Scott-Knott test at the 5\% significance level. ${ }^{\text {ns: }}$ non-significant in the $\mathrm{F}$ test at $5 \%$ probability.

For the accelerated aging parameter, seeds of larger diameter showed higher values. This result corroborates Vinhal-Freitas et al. (2011), who justified this result by pointing out the high temperature and high relative humidity of the air. This can promote a sharp increase in the metabolism of the seed, and when smaller ones are exposed to stress, their quality decreases more quickly. On the other hand, larger seeds will have more reserves to perform metabolic processes and thus greater capacity to originate normal seedlings.

By evaluating the parameter radicle dry mass, seed of larger diameter presented higher accumulation of phytomass. Similar results were obtained by Morais Soares et al. (2015) and Vinhal-Freitas et al. (2011) who linked them to the size or mass of seeds. This character reflects on the size of reserve tissues available for seedling development and directly influences the transference of mass from the cotyledons to the seedlings.

By observing the isolated factor treatment (Table 5), the results of parameters first count $(\mathrm{FC})$, germination rate $(\mathrm{G})$, field emergence $(\mathrm{FM})$, accelerated aging (AA) and radicle dry mass (RDM) indicate a non-significant difference among the different seed methods. Those results demonstrated that the use of polymers in seed treatment did not affect the physiological quality of the seeds. These results support the findings of Ludwig et al. (2011) and Brzezinski et al. (2015), who obtained no significant difference among treatments in soybeans. These previous studies indicated that the treatments did not affect the physiological quality obtained through germination and vigor tests.

Table 5. Means of the first count (FC), germination rate (G), emergence in the field (FE), accelerated aging (AA), radicle length (RL), hypocotyl length (HL), dry mass (DM) and moisture content (MC) test results from soybean seeds undergone different phytosanitary and polymers treatments.

\begin{tabular}{ccccccccc}
\hline Treatment & FC $(\%)$ & G $(\%)$ & FE $(\%)$ & AA $(\%)$ & RL $(\mathrm{cm})$ & HL $(\mathrm{cm})$ & DM $(\mathrm{mg})$ & MC $(\%)$ \\
\hline Control & $77 \mathrm{a}^{*}$ & $86 \mathrm{a}$ & $89 \mathrm{a}$ & $76 \mathrm{a}$ & $13.15 \mathrm{a}$ & $7.42 \mathrm{a}$ & $30.73 \mathrm{a}$ & $10.95 \mathrm{a}$ \\
Treat+pol & $80 \mathrm{a}$ & $91 \mathrm{a}$ & $86 \mathrm{a}$ & $75 \mathrm{a}$ & $14.35 \mathrm{a}$ & $6.25 \mathrm{~b}$ & $30.18 \mathrm{a}$ & $11.53 \mathrm{~b}$ \\
Treat/pol & $83 \mathrm{a}$ & $91 \mathrm{a}$ & $84 \mathrm{a}$ & $73 \mathrm{a}$ & $13.57 \mathrm{a}$ & $6.22 \mathrm{~b}$ & $29.8 \mathrm{a}$ & $11.60 \mathrm{~b}$ \\
Treat & $81 \mathrm{a}$ & $90 \mathrm{a}$ & $86 \mathrm{a}$ & $70 \mathrm{a}$ & $13.93 \mathrm{a}$ & $6.29 \mathrm{~b}$ & $30 \mathrm{a}$ & $11.41 \mathrm{~b}$ \\
\hline CV $(\%)$ & 6.43 & 6.79 & 5.03 & 5.42 & 7.6 & 9.9 & 5.97 & 0.5 \\
\hline
\end{tabular}

* Different letters in the columns indicate means with statistically significant differences in the Scott-Knott test at the 5\% significance level. 
However, there was a significant difference among the evaluated seed treatments when the variable hypocotyl length was accessed. The control presented higher values when compared to the other treatments. These results corroborate Ludwig et al. (2014) who suggests that these results are due to phytotoxic effect of the higher concentration of the chemical on the germitest paper during the initial growth of the seedling.

Generally speaking, seed treatment should not have a negative impact on the quality and early development of seed, but rather should protect them against adverse conditions. In order to consider a treatment appropriate, it should not be toxic to seeds so that the germination and seedling emergence are not negatively impacted (Keawkham et al., 2014).

Differences in the moisture content of the seeds were found. Those treated by any of the analyzed treatments presented higher values in comparison to control seeds. Even though the moisture contents were higher, the values are below the limit of $14 \%$ which, according to Smaniotto et al. (2014), is suitable for seed storage. Limiting the moisture contents to this value avoids mechanical damage and pathogen attacks that can lead to lower vigor.

\section{CONCLUSIONS}

The use of polymers associated with seed treatment is efficient in reducing losses by leaching, preventing a loss of about $20 \%$ of the active ingredient when compared to the seed treatment without polymer. No significant difference was found by comparing the water holding capacity and physiological quality of seed treated with two distinct polymer application methods. Moreover, larger seeds presented greater vigor, though the germination rate was similar.

\section{REFERENCES}

ACCINELli, C.; ABBAS, H. K.; LITTLE, N. S.; KOTOWICZ, J. K.; MENCARELLI, M.; SHIER, W. T. A. liquid bioplastic formulation for film coating of agronomic seeds. Crop Protection, v. 89, p. 123-128, 2016. https://doi.org/10.1016/j.cropro.2016.07.010

ARFAOUI, A.; EL HADRAMI, A.; DAAYF, F. Pre-treatment of soybean plants with calcium stimulates ROS responses and mitigates infection by Sclerotinia sclerotiorum. Plant $\begin{array}{llllll}\text { Physiology and Biochemistry, v. 122, p. 121-128, } 2018 . & \end{array}$ https://doi.org/10.1016/j.plaphy.2017.11.014

AVELAR, S. A. G.; SOUSA, F. V. D.; FISS, G.; BAUDET, L.; PESKE, S. T. The use of film coating on the performance of treated corn seed. Revista Brasileira de Sementes, v. 34, n. 2, p. 186-192, 2012. http://doi.org/10.1590/S0101-31222012000200001

BALARDIN, R. S.; SILVA, F. D. L.; DEBONA, D.; CORTE, G. D.; FAVERA, D. D.; TORMEN, N. R. Tratamento de sementes com fungicidas e inseticidas como redutores dos efeitos do estresse hídrico em plantas de soja. Ciência Rural, v.41, n.7, p.1120-1126, 2011. http://doi.org/10.1590/S0103-84782011000700002

BRASIL. Ministério da Agricultura, Pecuária e Abastecimento. Regras para Análise de Sementes. Brasília: Mapa/ACS, 2009. 395 p.

BRZEZINSKI, C. R.; HENNING, A. A.; ABATI, J.; HENNING, F. A.; FRANÇA-NETO, J. D. B.; KRZYZANOWSKI, F. C.; ZUCARELI, C. Seeds treatment times in the establishment and yield performance of soybean crops. Journal of Seed Science, v. 37, n. 2, 147-153, 2015. http://doi.org/10.1590/2317-1545v37n2148363 
CAMozZATO, V. A.; PESKE, S. T.; POSSENTI, J.; MENDES, A. S. Desempenho de cultivares de soja em função do tamanho das sementes. Revista brasileira de sementes, v. 31, n. 1, p. 288-292, 2009. http://doi.org/10.1590/S0101-31222009000100032

CARVAlHO, N. M.; NAKAGAWA, J. Sementes: Ciência, Tecnologia e Produção. 5. ed. Jaboticabal: Funep, 2012. 590 p.

CASTRO, N. R. A.; RIGITANO, R. L. D. O.; LIMA, J. M. D.; GUERREIRO, M. C. Lixiviação do inseticida thiamethoxam em macrolisímetros de duas classes de solo. Ciência e agrotecnologia, v. 32, n. 6, p. 1818-1823. 2008. http://doi.org/10.1590/S141370542008000600021

FAGUNDES, L. K.; NUNES, U. R.; PRESTES, O. D.; FERNANDES, T. S.; LUDWIG, E. J.; SAIBT, N. Rice seed treatment and recoating with polymers: physiological quality and retention of chemical products. Revista Caatinga, v. 30 n. 4, p. 920-927, 2017 http://doi.org/10.1590/1983-21252017v30n412rc

HESLER, L. S.; ALLEN, K. C.; LUTTRELL, R. G.; SAPPINGTON, T. W.; PAPIERNIK, S. K. Early-season pests of soybean in the United States and factors that affect their risk of infestation. Journal of Integrated Pest Management, v. 9, n. 1, p. 19, 2018. https://doi.org/10.1093/jipm/pmx028

IOANNOU, A.; GOHARI, G.; PAPAPHILIPPOU, P.; PANAHIRAD, S.; AKBARI, A.; DADPOUR, M. R.; KRASIA-CHRISTOFOROU, T.; FOTOPOULOS, V. Advanced nanomaterials in agriculture under a changing climate: The way to The future? Environmental and Experimental Botany, v. 176, p. 1-14, 2020. https://doi.org/10.1016/j.envexpbot.2020.104048

KEAWKHAM, T.; SIRI, B.; HYNES, R. K. Effect of polymer seed coating and seed dressing with pesticides on seed quality and storability of hybrid cucumber. Australian Journal of Crop Science, v. 8, n. 10, p. 1415, 2014.

KEMMERICH, M.; RIZZETTI, T. M.; MARTINS, M. L.; PRESTES, O. D.; ADAIME, M. B.; ZANELLA, R. Optimization by central composite design of a modified QuEChERS method for extraction of pesticide multiresidue in sweet pepper and analysis by ultrahigh-performance liquid chromatography-tandem mass spectrometry. Food analytical methods, v. 8, n. 3, p. 728-739, 2014. https://doi.org/10.1007/s12161-014-9951-2

KOPPER, A. C.; MALAVASI, M. DE M.; MALAVASI, U. C. Influência da temperatura e do substrato na germinação de sementes de Cariniana estrellensis (Raddi) Kuntze. Revista Brasileira de Sementes, v. 32, n. 2, p. 160-165, 2010. http://doi.org/10.1590/S010131222010000200020

LIMA, L. B.; DA SILVA, P. A.; GUIMARÃES, R. M.; OLIVEIRA, J. A. Peliculização e tratamento químico de sementes de algodoeiro. Ciência e Agrotecnologia, v. 30, p. 10911098, 2006. http://doi.org/10.1590/S1413-70542006000600007

LUDWIG, E. J.; NUNES, U. R.; MERTZ, L. M.; DA SILVA, J. R.; NUNES, S. C. P. Vigor e produção de sementes de crambe tratadas com fungicida, inseticida e polímero. Científica, v. 42, n. 3, p. 271-277, 2014. http://doi.org/10.15361/1984$5529.2014 \mathrm{v} 42 \mathrm{n} 3 \mathrm{p} 271-277$

LUDWIG, M. P.; LUCCA FILHO, O. A.; BAUDET, L.; DUTRA, L. M. C.; AVELAR, S. A. G.; CRIZEL, R. L.; OLIVEIRA, S. Eficiência do recobrimento de sementes de soja em equipamento com sistema de aspersão. Ciência Rural, v. 41, n. 4, 2011. http://doi.org/10.1590/S0103-84782011005000023 
MORAIS SOARES, M.; CARVALHO, J. S.; H., SIMÕES, M. G.; PAZZIN, D.; JUNIO DA SILVA, L. Estresse hídrico e salino em sementes de soja classificadas em diferentes tamanhos. Pesquisa Agropecuária Tropical, v. 45, n. 4, 2015. http://doi.org/10.1590/1983-40632015v4535357

PADUA, G. P.; ZITO, R. K.; ARANTES, N. E.; NETO, F. Influência do tamanho da semente na qualidade fisiológica e na produtividade da cultura da soja, Revista Brasileira de Sementes, v. $32, \quad \mathrm{n} \quad 3$ p. 009-016, 2010. http://doi.org/10.1590/S010131222010000300001

SEGALIN, S. R.; BARBIERI, A. P. P.; HUTH, C.; BECHE, M.; MATTIONI, N. M.; MERTZ, L. M. Physiological quality of soybean seeds treated with different spray volumes. Journal of Seed Science, v. 35, n. 4, p. 501-509, 2013. http://doi.org/10.1590/S231715372013000400012

SMANIOTTO, T. A. D. S.; RESENDE, O.; MARÇAL, K. A.; DE OLIVEIRA, D. E.; SIMON, G. A. Physiological quality of soybean seeds stored in different conditions. Revista Brasileira de Engenharia Agrícola e Ambiental, v. 18, n. 4, p. 446-453, 2014. http://doi.org/10.1590/S1415-43662014000400013

VIJAYA MAHANTESH, B. N.; RAI, P. K.; SRIVASTAVA, D. K.; BARA, B. M.; KUMAR, R. Effects of polymer seed coating, fungicide seed treatment and storage duration on seedling characteristics of cotton (Gossypium hirsutum) seeds. Journal of Pharmacognosy and Phytochemistry, v. 6, n. 4, p. 534-536, 2017.

VINHAL-FREITAS, I. C.; GARCIA JUNIOR, J. E.; SEGUNDO, J. P.; VILARINHO, M. S. Germinação e vigor de sementes de soja classificadas em diferentes tamanhos. Agropecuária Técnica, v. 32, n. 1, p. 108-114, 2011.

ZHANG, F.; GE, H.; ZHANG, F.; GUO, N.; WANG, Y.; CHEN, L.; LI, C. Biocontrol potential of Trichoderma harzianum isolate T-aloe against Sclerotinia sclerotiorum in soybean. Plant Physiology and Biochemistry, v. 100, p. 64-74, 2016. https://doi.org/10.1016/j.plaphy.2015.12.017 